Environment Conservation Journal 15(3) 51-54, 2014

ISSN 0972-3099 (Print) 2278-5124 (Online)

Abstracted and Indexed

\title{
Standardization of spacing and weed management practices in SRI system of rice cultivation under organic conditions in relation to sustainable agriculture in the changing scenario of climate
}

\author{
Rameshwar $\bowtie$, J.P. Saini, Sanjay Chadha, Punam and R.G.Upadhyay
}

Received:15.07.2014

Revised: 21.09.2014

Accepted:22.11.2014

\begin{abstract}
A field experiment was conducted during kharif seasons of 2009 \& 2010 at Model Organic Farm of Department of Organic agriculture, CSK Himachal Pradesh Krishi Vishvavidyalya Palampur in factorial randomized block design with three replications consisting of eight treatment combinations. The treatments included two methods of weeding (mechanical weeding with cono weeder $\&$ hand weeding) and 4 spacings $(25 \times 25,30 \times 30,20 \times 20$ and $30 \times 20 \mathrm{~cm})$. Rice variety RP-2421 was transplanted in second week of July during both the years following all organic packages of practices. The weeding was done at $20 \& 40$ days after transplanting rice. The dominant species of weeds were Echinochloa crusgalli, Digitaria sanguinalis and Panicum dichotomiflorum among grasses; Cyperus iria and Cyperus difforimis among sedges and Aeschynomera indica, Ammania spp and Commelina benghalensis among broadleaved weeds.The experimental results revealed that 2 mechanical weedings with cono-weeder at $20 \& 40$ DAT resulted in significantly higher values of yield attributes $v i z$. effective tillers $/ \mathrm{m}^{2} \&$ panicle length and hence higher paddy yield and lower weed dry weight over hand weeding twice ( 20 \& 40 DAT). However, grains/ panicle and 1000 grain weight did not vary significantly during both the years. Among spacings $30 \times 30 \mathrm{~cm}$ being at par with $25 \times 25 \mathrm{~cm} \& 30 \times 20 \mathrm{~cm}$ recorded significantly higher paddy yield and lower weed dry weight over $20 \times 20 \mathrm{~cm}$ during both the years. The interactions between method of weedings\& spacing were observed to be non-significant during both the years of study.
\end{abstract}

Keywords: organic, spacing, weed management

\section{Introduction}

Rice is a major cereal crop of our country. The total annual production of rice in the country is hovering around 90 million tones from an area of about 43 million hectares. At present, the rate of population growth in India, would require about 120 million tones of rice by 2020 i.e. at least 2 million tones of additional rice per year from the limited land area using resource base and production factors most efficiently. At the same time water is one of the most precious and major factors in rice production. The water requirement of flood-irrigated rice is two to three times more than other cereal crops such as wheat and maize. More than 70 per cent of the country's ground and surface water is being used for agriculture of which two third is allocated to rice cultivation. Rice crop requires about 30005000 litres of water for production

\section{Author's Address}

College of Forestry and Hill Agriculture, Uttarakhand University of Horticulture \& Forestry, Tehri Garhwal Uttarakhand

E-mail: drrameshwar@gmail.com of $1 \mathrm{Kg}$ rice. So rice production has to take place with less land and saved water. SRI (system of rice intensification) has the potential to meet the increased rice demand and at the same time conserve the natural resource base for prosperity. SRI requires considerably fewer seeds $(8 \mathrm{~kg} / \mathrm{ha})$ while BRRI (Bangladesh Rice Research Institute) method and farmers practices required 30 and 60 $\mathrm{kg}$ / ha seeds, respectively (Latifa et al., 2005). SRI is an improved method of rice cultivation developed to overcome the problem of rice cultivator. It produces more yields with almost one half of the quantum of water required under conventional method (flood irrigation) of rice cultivation. The five major components of the SRI are the use of young seedlings at the two-leaf stage (8-15 days with one seedling per hill), wide plant spacing of $25 \mathrm{~cm} \times 25 \mathrm{~cm}$ to as much as $50 \mathrm{~cm} \times 50$ $\mathrm{cm}$, a minimum of three hand weedings at 10-12, 22-25 and 40-42 days after transplanting, the addition of organic matter (manure and/or compost) to supply adequate nutrients and intermittent

Copyright by ASEA 51

All rights of reproduction in any form reserved 
drainage and soil drying for soil aeration during the vegetative stage. SRI promotes soil biotic activities in and around plant roots through liberal application of compost and weeding with a rotating hoe that aerates the soil.Rice suffers more from weed competition as weeds suppress the growth at early stages of crop growth. The damage caused by the weeds is often not noticed at later stages. In addition to direct effect on the productivity of the crop, weeds reduce the input use efficiency; these are more efficient in absorbing nutrients and moisture than the crop plants. Weeds interfere with agricultural operations.

Latifa et al., (2005) remarked as a result of one of their studies that the combination of wider spacing and less water-use in SRI provides ideal conditions for weed growth, which means that frequent weeding is necessary. But at the same time wider spacing provides an option to go for mechanical weeding with the help of conoweeder. Mrunalini and Ganesh (2008) compared weeding with the use of conoweeder in paddy crop grown in SRI method against conventional method of hand weeding and found that conoweeder enhanced the pace of work and doubled the productivity, saved time up to 76 per cent and optimized the human effort through improved postures and reduced the muscular fatigue as compared with the hand weeding process. Singh et al., (2008) have also concluded from their study that weeding in rice with conoweeder saves labour and time which is especially suitable for local hilly conditions. The degree of competition and extent of yield loss vary with spacings and rice culture. On an average $15-$ $20 \%$ yield reduction is caused in transplanted rice. Hence, the present study was undertaken to find out the best spacing \& weed management practice to minimize the yield loss in SRI system of rice cultivation under organic conditions.

\section{Material and Methods}

The field experiments were conducted during kharif seasons of 2009 \& 2010 at Model Organic Farm of Department of Organic Agriculture, Chaudhary Sarwan Kumar Himachal Pradesh Krishi Vishvavidyalya Palampur. The experimental site was located at $32^{\circ} .4^{\prime} \mathrm{N}$ latitude and $76^{\circ} .3^{\prime} \mathrm{E}$ longitudes at an elevation of about 1224 meters above mean sea level in North-Western Himalayas.
The area represents the mid hill wet temperate zone of Himachal Pradesh. The soil of the experimental field was silty clay loam in texture, acidic in reaction ( $\mathrm{pH} 5.8)$, low in organic carbon $(0.60 \%)$, low in available nitrogen $(220.4 \mathrm{Kg} / \mathrm{ha})$ and phosphorus $(6.0 \mathrm{Kg} / \mathrm{ha}) \&$ medium in available potassium $(268.0 \mathrm{Kg} / \mathrm{ha})$. Crop was fertilized with well decomposed farm yard manure, uniformly spread and incorporated in the field @ 10 t/ha prior to ploughing. The experiment was laid out in factorial randomized block design with three replications and eight treatment combinations. The treatments included two methods of weeding (mechanical weeding with cono weeder \& hand

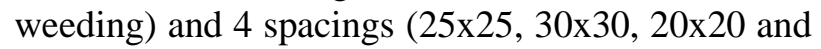
$30 \times 20 \mathrm{~cm}$ ). Rice variety RP-2421 was transplanted in second week of July during both the years following all organic packages of practices. The weeding was done at $20 \& 40$ days after transplanting of rice seedlings. Different growth parameters, yield contributing characters and paddy yield were recorded along with the weed dry weight.

\section{Results and Discussion \\ Effect of weeding methods}

The grasses weeds included Echinochloa crusgalli, Digitaria sanguinalis and Panicum dichotomiflorum, the broad leaf weeds included Commelina benghalensis, Ammania spp and Aeschynomene indica, where as sedges included Cyperus spp (Cyperus iria and Cyperus difforimis) and Scirpus spp. Mechanical method of weeding produced $29.3 \& 28.5 \%$ less total dry matter of weeds as compared to hand weeding in 2009 \& 2010 respectively (Table 1). Mechanical method of weed control proved significantly better than hand weeding irrespective of different methods of weed control and in different years of study except in broad leaf weeds where methods of weeding were non significant in both years of study. Mechanical method of weed control was efficient in controlling both grassy weeds and sedges and there was a reduction of 33.4 and $32.3 \%$ dry matter accumulation of grassy weeds and $25.9 \& 28.2 \%$ in sedges with mechanical weeding as compared to hand weeding in 2009 and 2010 respectively. The better control of weeds with mechanical method may be due to complete and effective control of 
weeds as compared to hand weeding. Weeding plant height, panicle length and grains / panicle methods significantly affected the effective during the first year of experimentation (Table 2).

tillers $/ \mathrm{m}^{2}$ and paddy yield during both years and

Table 1: Effect of weeding methods and spacings on weed dry weight $\left(\mathrm{g} / \mathrm{m}^{2}\right)$ of different weeds in SRI system of rice cultivation

\begin{tabular}{|l|l|l|l|l|l|l|l|l|}
\hline Treatment & \multicolumn{2}{l}{ Grassy Weeds } & \multicolumn{2}{l|}{ Broadleaf weeds } & \multicolumn{2}{l|}{ Sedges } & \multicolumn{2}{l|}{ Total } \\
\hline & $\mathbf{2 0 0 9}$ & $\mathbf{2 0 1 0}$ & $\mathbf{2 0 0 9}$ & $\mathbf{2 0 1 0}$ & $\mathbf{2 0 0 9}$ & $\mathbf{2 0 1 0}$ & $\mathbf{2 0 0 9}$ & $\mathbf{2 0 1 0}$ \\
\hline Weeding Methods & & & & & & & & \\
\hline Mechanical & 18.07 & 14.47 & 1.541 & 2.157 & 13.19 & 10.7 & 32.8 & 27.3 \\
\hline Handweeding & 27.14 & 21.39 & 1.438 & 1.910 & 17.82 & 14.9 & 46.4 & 38.2 \\
\hline CD $(\mathrm{P}=0.05)$ & 3.354 & 4.132 & NS & NS & 2.177 & 2.74 & 5.7 & 7.2 \\
\hline Spacings (cm) & & & & & & & & \\
\hline 25x25 & 25.81 & 15.09 & 2.922 & 1.848 & 19.97 & 13.9 & 48.7 & 30.8 \\
\hline $30 \times 30$ & 18.92 & 15.46 & 2.548 & 2.248 & 14.92 & 10.4 & 36.4 & 28.1 \\
\hline $20 \times 20$ & 25.95 & 19.36 & 3.114 & 2.370 & 22.84 & 17.8 & 51.9 & 39.5 \\
\hline $30 \times 20$ & 17.54 & 16.63 & 1.376 & 1.597 & 15.48 & 14.4 & 34.4 & 32.6 \\
\hline CD $(\mathrm{P}=0.05)$ & 4.342 & 3.382 & 0.340 & 0.214 & 3.88 & 2.64 & 8.4 & 6.3 \\
\hline
\end{tabular}

Table 2: Effect of weeding methods and spacings on plant height, yield and yield attributes in SRI system of rice cultivation

\begin{tabular}{|c|c|c|c|c|c|c|c|c|c|c|c|c|}
\hline \multirow[t]{2}{*}{ Treatment } & \multicolumn{2}{|c|}{$\begin{array}{l}\text { Plant } \\
\text { height } \\
\text { (cm) }\end{array}$} & \multicolumn{2}{|c|}{$\begin{array}{l}\text { Effective } \\
\text { tillers/m² (No.) }\end{array}$} & \multicolumn{2}{|c|}{$\begin{array}{l}\text { Panicle } \\
\text { length }(\mathrm{cm})\end{array}$} & \multicolumn{2}{|c|}{$\begin{array}{l}\text { Grains/panicle } \\
\text { (No.) }\end{array}$} & \multicolumn{2}{|c|}{$\begin{array}{l}\text { '000 grain } \\
\text { weight } \\
\text { (g) }\end{array}$} & \multicolumn{2}{|c|}{$\begin{array}{l}\text { Paddy yield } \\
\text { (q/ha) }\end{array}$} \\
\hline & 2009 & 2010 & 2009 & 2010 & 2009 & 2010 & 2009 & 2010 & 2009 & 2010 & 2009 & 2010 \\
\hline \multicolumn{13}{|c|}{ Weeding Methods } \\
\hline Mechanical & 89.8 & 91.2 & 245.2 & 241.8 & 15.7 & 16.1 & 87.5 & 90.3 & 23.2 & 21.5 & 23.5 & 22.4 \\
\hline Handweeding & 84.3 & 90.4 & 239.5 & 237.6 & 13.8 & 15.8 & 84.8 & 89.2 & 22.7 & 21.2 & 20.1 & 18.8 \\
\hline $\mathrm{CD}(\mathrm{P}=0.05)$ & 4.2 & NS & 4.7 & 3.5 & 1.5 & NS & 2.5 & NS & NS & NS & 2.3 & 2.6 \\
\hline \multicolumn{13}{|l|}{ Spacings $(\mathbf{c m})$} \\
\hline $25 \times 25$ & 88.2 & 91.5 & 245.1 & 239.5 & 15.3 & 15.8 & 86.5 & 90.1 & 22.4 & 21.1 & 22.7 & 20.3 \\
\hline $30 \times 30$ & 87.3 & 90.4 & 243.2 & 239.9 & 15.2 & 18.0 & 88.2 & 89.4 & 24.0 & 22.0 & 23.5 & 22.2 \\
\hline $20 \times 20$ & 84.7 & 90.1 & 238.7 & 239.3 & 13.6 & 14.1 & 83.6 & 90.3 & 22.2 & 20.4 & 19.5 & 18.1 \\
\hline $30 \times 20$ & 88.0 & 91.2 & 242.4 & 240.1 & 14.9 & 15.9 & 86.3 & 89.2 & 23.2 & 21.9 & 21.9 & 21.9 \\
\hline $\mathrm{CD}(\mathrm{P}=0.05)$ & 2.7 & NS & 3.1 & NS & 1.2 & 2.5 & 1.5 & NS & NS & 0.5 & 2.5 & 2.1 \\
\hline
\end{tabular}

The experimental results revealed that two mechanical weeding can be attributed to the mechanical weedings with Conoweeder at 20 and effective weed control in this treatment. It is 40 DAT resulted in significantly higher values of evident from the data in Table 1 that the mechanical effective tillers $/ \mathrm{m}^{2}$ during both the years. Panicle weeding resulted in 29.1 and $28.5 \%$ lower weed length and grains/ panicle were also higher in dry matter accumulation as compared to hand mechanical weeding over hand weedings during weedings during 2009 and 2010 respectively. both years but the results were non- significant Because of lower weed dry weight and higher during second year. Though 1000 grain weight did values of yield attributes, the paddy grain yield was not differ significantly but the values were higher in 5.8 and $19.1 \%$ higher, in mechanical weeding over mechanical weeding. The higher values of almost hand weedings, respectively in first and second all the yield attributes and plant height in year of study. 


\section{Effect of spacing}

Different spacings significantly showed their effect by decreasing the weed dry weight in wider row spacing (30x20 and $30 \times 30 \mathrm{~cm}$ ) as compared to narrower row spacing of $(25 \times 25$ and $20 \times 20 \mathrm{~cm})$ in all types of weeds and total dry matter, whereas, varying the plant to plant spacing did not effect the weed dry weight in different methods of weeding and the total weed dry weight in the first year of study. In the second year of study $30 \times 30 \mathrm{~cm}$ spacing in rice produced less total dry matter weight as compared to $20 \times 20 \mathrm{~cm}$. This may be due to the fact that in wider row spacing it was easy to run the cono-weeder and weed out the different weeds effectively, whereas, in narrower spacing it was difficult to control the weeds because of difficulty in movement of the conoweeder. Spacing affected most of the yield attributes and yield of paddy (Table 1). Wider spacing of $30 \times 30$, $25 \times 25$ and $30 \times 20 \mathrm{~cm}$ being at par with one another resulted in significantly higher plant height, effective tillers $/ \mathrm{m}^{2}$ and grains/ panicle over 20 x20 cm during 2009 where as the differences were non significant during 2010. Similarly panicle length in all wider spacings $(30 \times 30,25 \mathrm{x}$ 25 and $30 \times 20 \mathrm{~cm}$ ) were statistically equal but significantly higher than $20 \times 20 \mathrm{~cm}$ spacing during both the years of study. 1000 grain weight was not affected significantly by spacing in 2009, however during $2^{\text {nd }}$ year, $30 \times 30$ spacing being at par with $25 \times 25$ and $30 \times 20 \mathrm{~cm}$ spacing resulted in significantly higher 1000 grain weight over narrow spacing of $20 \times 20 \mathrm{~cm}$. Higher values of almost all yield attributes of paddy in wider spacings may be attributed to the better weed control particularly with conoweeder as compared to the narrow spacing as is reflected in weed dry weight which was significantly less in wider spacing as compared to the narrow spacing of $20 \times 20 \mathrm{~cm}$ (Table 2). Also, in narrow spacing, the conoweeder might have damaged some of the roots of paddy which ultimately resulted in lowest plant height and yield attributes of paddy. Due to higher values of all the yield attributes and lower weed dry weight, 30x 30 $\mathrm{cm}$ spacing being at par with $25 \times 25$ and $30 \times 20$ $\mathrm{cm}$ spacing produced $19.2 \%$ and $22.7 \%$ higher paddy yield over $20 \times 20 \mathrm{~cm}$ during first and second year of study, respectively. Thakur et al (2009) suggested that the optimum spacing under the system of rice intensification in short-and medium-duration cultivars was $25 \mathrm{~cm} \times 25 \mathrm{~cm}$ for the long duration cultivar in terms of grain yield. The long-duration cultivar gave $31.2 \%$ more grain yield in the system of rice intensification than the conventional system at $25 \mathrm{~cm} \times 25 \mathrm{~cm}$ spacing. Thin tillers and short panicles with less number of grains were responsible for reduction in grain yield at narrow spacing in the system of rice intensification. The wider spacing improved different growth parameters in BRRI dhan 32 (at 40-60 DAT) combinations under SRI conditions in Bangladesh Islam et al (2005). Similarly Borkar et al. (2008) found that grain yield and straw yield increased significantly with the increased spacing which recorded the highest grain yield and straw yield over narrow spacings.

It is concluded that growing of rice at a spacing of $30 \times 30 \mathrm{~cm}$ along with two mechanical weedings with cono-weeder at $20 \& 40$ DAT emerged to be best management practice in SRI system of rice cultivation under organic conditions.

\section{References}

Borkar, L.S., Khawale, V.S., Raut, P.B., Patil,T.S. and Kolte, H.S. 2008. Studies on spacing and nitrogen management under system of rice intensification (SRI).Journal of Soils and Crops 18(2): 438-441

Islam, A.K., Islam M.R., Hossain, M.M., Karim, K.M.R. and Alam, K.M. 2005. Performance of growth contributing characters through spacing and variety under the system of rice intensification (SRI) technique.International Journal of Sustainable Agricultural Technology. 1(4): 21-29

Latifa M.A., Islama M.R., Alia M.Y. and Salequeb, M.A. 2005.Validation of the system of rice intensification (SRI) in Bangladesh.Field Crops Research 93 (2005) 281-292

Mrunalini, A and Ganesh, M. 2008. Work load on women using conoweeder in SRI method of paddy cultivation. Oryza. 45(1): 58-61

Singh, Sukhbir., Verma, H.N. and Vatsa, D.K. 2008. Prospects of paddy cultivation mechanization in hills of Himachal Pradesh.Agricultural Mechanization in Asia, Africa andLatin America.39 (3): 46-49

Thakur, A.K., Chaudhari, S.K.; Singh, R. and Ashwani-Kumar. 2009. Performance of rice varieties at different spacing grown by the system of rice intensification in eastern India. Indian Journal of Agricultural Sciences 79(6): 443-447. 